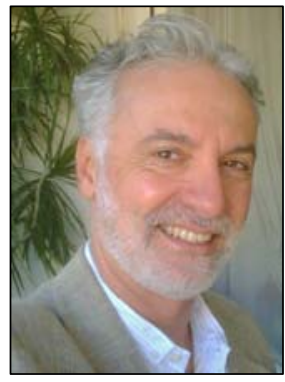

GLobal Views of Local Food Systems Reflections on the growing worldwide local food movement RAMI ZURAYK

\title{
Family farmers are struggling everywhere
}

Published online August 2010

Copyright (C) 2010 by New Leaf Associates, Inc.

Family farming is not doing very well around the world. In the U.S., the oldest continuously operating farm, Tuttle farm, founded in 1632 in Dover, New Hampshire, is currently up for sale. The Boston Globe ran a story about it, ${ }^{1}$ and many in New England and beyond are lamenting this sad event. Farm owner Will Tuttle expressed his feelings very clearly: "Looking forward, I don't see much opportunity for small farms to thrive. It's a tough grind." His words echo those of Morse Pitts, ${ }^{2}$ who has been farming in New York's Hudson Valley for 30 years. Pitts is recognized as a

Rami Zurayk is professor at the Faculty of Agricultural and Food Sciences at the American University of Beirut, Lebanon. He studied at the American University of Beirut and at Oxford University, UK. His research addresses issues at the nexus of food, landscapes, and livelihoods. He is an active member of Lebanese civil society and a founder of Slow Food Beirut. He can be contacted at ramizurayk@gmail.com.

${ }^{1}$ See the story at www.boston.com/news/local/ new hampshire/articles/2010/07/27/nations oldest running family farm put on market in nh/ ${ }^{2}$ See http://prospect.org/cs/articles?article=slowed food revolution pioneer of local, sustainable food and has been celebrated by the leaders of the Local Food movement such as Slow Food founding member Alice Waters. But Pitts is quitting farming, even though he has been doing everything by the "local" book, and successfully too: he sells at high prices directly to consumers; his clientele is large and faithful; and his produce is sold in New York's Union Square Market. Yet according to his calculations, his earnings are just USD7 an hour. Considering the amount of time and effort he deploys to produce sustainable food, this is - to say the least — unsustainable.

But what brought New England and New York into a column dedicated to issues of the Global South? Well, for one, I happen to be writing this from New England, where I am spending a few weeks on leave from the American University of Beirut, where I usually teach, to participate in the EcoGastronomy program offered by the University of New Hampshire. The program, the first of its kind in the U.S., is offered as a dual major in collaboration with the University of Gastronomic Sciences (UGS) in Pollenzo, Italy. The UGS, also known as "the Slow Food 
University," "takes students to the field, the kitchen, the lab and Italy to study the complexities of sustainable food systems." 3 In return, students from UGS following a similar program, spending a term at UNH, where they get to learn about family farming and local, sustainable food in New England. In other words, the EcoGastronomy students are trained to be aware of the links between field, food, and farmers, which is unique in the academic world.

My stay at UNH has given me the opportunity to try and better understand farming in the U.S.

Having studied in France and Britain and worked extensively in the Arab world, I find American agriculture a land of mystery where thousands of community supported agriculture programs rub shoulders with industrial biofuel production. After all, the U.S. is the country that gave us both the locavore and the supersized meal!

The realization that family farming is in disarray in places like New England came as a bit of a shock to me, in view of the flurry of farmers' markets and of restaurants and eateries that advertise their use of locally produced food. Surely if there are so many people who are eating local, sustainably produced food, the laws of the market dictate that local, sustainable farmers must be doing better, not worse. This "paradox of plenty" certainly deserves deeper study.

The global demand for sustainably produced food, specifically organic food, has grown so much and so rapidly in the past decade that it has sometimes resulted in aberrations, and not only in the U.S. Take Egypt for instance, whose precious water resources are used by large-scale farms to produce

${ }^{3}$ See more at www.unh.edu/news/cj nr/2008/sept/ bp2eco.cfm organic fruits and vegetables for export to supermarkets across Europe. However, Egypt is a food-deficit country where 20 percent of the people live below the poverty line on less than USD1 a day. It is also a recipient of food aid, ${ }^{4}$ and a country where many rural and urban people are food insecure! The small- and medium-sized Egyptian farmers face difficulties similar to their French and American counterparts: they are unable to compete with the economies of scale and the control over the value chain that characterize capitalist agriculture. Our technical and scientific advances in sustainable agriculture, including organic farming, have been appropriated by the industrial food system to satisfy the growing demand for "healthy" food by global elites at the cost of reduced food security.

Research into how to improve the environmental sustainability of farming has gained strength in universities and research centers over the past decade. Environmentally sound farming is now of interest to granting agencies, and many schools of agriculture are refocusing their curricula on sustainable agriculture. This new interest has permeated other sectors: for example, the adoption of sustainable farming practices is often requested today as a precondition to agriculture development aid to countries of the global South.

The question remains whether any form of agriculture truly can be considered sustainable if it does not contribute to sustainable livelihoods of small farmers and to the food security of the poor. And while universities and research centers may have deployed serious efforts to discover and test new techniques and technologies to make agriculture less environmentally damaging, they

${ }^{4}$ www.wfp.org/countries/egypt 
have done little to ensure the survival of small- and medium-sized farmers who constitute the vast majority of the poor food producers of the planet.

Organizations in the global Food Movement, including groups such as La Via Campesina and Slow Food, have stepped in to plug that gap. Many are attempting to change the rules of the game in favor of small- and medium-sized farmers, albeit in very different ways. La Via Campesina, for example, is an activist international movement that aims at achieving social justice and food sovereignty. ${ }^{5}$ Its 148 member organizations come from 69 countries from Asia, Africa, Europe, and the Americas, but they organize and act in unison and provide mutual support. Slowly but surely, they are making their voices heard at all the food forums. Organizations such as Slow Food ${ }^{6}$ operate in a very different manner. Slow Food started as a reaction against global fast-food companies, and in spite of its declared ethos of "good, clean and fair," it is better known for its convivial approach to the appreciation of sustainably produced local food rather than for its social justice agenda. One common critique of Slow Food is that the "fair" component of the triptych too often is treated as the poor cousin. However, it is specifically this component that is most needed for the survival of small- and medium-sized farmers - both in the Global North, where the welfare safety nets are being dismantled, and in the Global South, where these nets have never existed.

The tensions in the food system, in the food research agendas, and in the food movement partly explain the paradox of plenty. And while the shift toward sustainable agriculture is today inescapable for small as for big farmers, in the North as in the South, it appears that the food security of the poor and the survival of rural society may need more politics and less lifestyle.

\footnotetext{
${ }^{5}$ http://viacampesina.org/en/index.php?option $=\mathrm{com}$ content\&view $=$ category\&layout $=$ blog \&id $=27 \&$ Itemid $=44$ ${ }^{6}$ www.slowfood.com
} 
Journal of Agriculture, Food Systems, and Community Development ISSN: 2152-0798 print / 2152-0801 online www.AgDevJournal.com 